Correspondence

Shin Haruta

sharuta@tmu.ac.jp

Received 17 February 2011

Accepted 31 March 2011

\section{Detection of active, potentially acetate-oxidizing syntrophs in an anaerobic digester by flux measurement and formyltetrahydrofolate synthetase (FTHFS) expression profiling}

\author{
Tomoyuki Hori, ${ }^{1,2}$ Daisuke Sasaki, ${ }^{1}$ Shin Haruta, ${ }^{1,3}$ Toru Shigematsu, ${ }^{4}$ \\ Yoshiyuki Ueno, ${ }^{5}$ Masaharu Ishii ${ }^{1}$ and Yasuo Igarashi ${ }^{1}$
}

\author{
${ }^{1}$ Department of Biotechnology, Graduate School of Agricultural and Life Sciences, The University of \\ Tokyo, Yayoi 1-1-1, Bunkyo-ku, Tokyo 113-8657, Japan \\ ${ }^{2}$ Bioproduction Research Institute, National Institute of Advanced Industrial Science and \\ Technology, Tsukisamu-Higashi 2-17-2-1, Toyohira-ku, Sapporo 062-8517, Japan \\ ${ }^{3}$ Graduate School of Science and Engineering, Tokyo Metropolitan University, Minami-Osawa 1-1, \\ Hachioji-shi, Tokyo 192-0397, Japan \\ ${ }^{4}$ Department of Food Science, Faculty of Applied Life Sciences, Niigata University of Pharmacy and \\ Applied Life Sciences, Niigata 956-8603, Japan \\ ${ }^{5}$ Kajima Technical Research Institute, Tobitakyu 2-19-1, Chofu-shi, Tokyo 182-0036, Japan
}

Syntrophic oxidation of acetate, so-called reversed reductive acetogenesis, is one of the most important degradation steps in anaerobic digesters. However, little is known about the genetic diversity of the micro-organisms involved. Here we investigated the activity and composition of potentially acetate-oxidizing syntrophs using a combinatorial approach of flux measurement and transcriptional profiling of the formyltetrahydrofolate synthetase (FTHFS) gene, an ecological biomarker for reductive acetogenesis. During the operation of a thermophilic anaerobic digester, volatile fatty acids were mostly depleted, suggesting a high turnover rate for dissolved $\mathrm{H}_{2}$, and hydrogenotrophic methanogens were the dominant archaeal members. Batch cultivation of the digester microbiota with ${ }^{13} \mathrm{C}$-labelled acetate indicated that syntrophic oxidation accounted for $13.1-21.3 \%$ of methane production from acetate. FTHFS genes were transcribed in the absence of carbon monoxide, methoxylated compounds and inorganic electron acceptors other than $\mathrm{CO}_{2}$, which is implicated in the activity of reversed reductive acetogenesis; however, expression itself does not distinguish whether biosynthesis or biodegradation is functioning. The mRNA- and DNA-based terminal RFLP and clone library analyses indicated that, out of nine FTHFS phylotypes detected, the FTHFS genes from the novel phylotypes I-IV in addition to the known syntroph Thermacetogenium phaeum (i.e. phylotype V) were specifically expressed. These transcripts arose from phylogenetically presumed homoacetogens. The results of this study demonstrate that hitherto unidentified phylotypes of homoacetogens are responsible for syntrophic acetate oxidation in an anaerobic digester.

\footnotetext{
Abbreviations: HS score, homoacetogen similarity score; IC, inorganic carbon; SIM, selected ion monitoring; SS, suspended solids; TOC, total organic carbon; T-RF, terminal restriction fragment; T-RFLP, terminal RFLP; VFAs, volatile fatty acids.

The GenBank/EMBL/DDBJ accession numbers for the sequences discussed in this study are AB523737 and AB523738 for the archaeal 16S rRNA gene, AB353082-AB353096 for environmental clones of the FTHFS genes and transcripts, and AB523739 for the FTHFS homologue from Thermacetogenium phaeum.
}

\section{INTRODUCTION}

In methanogenic environments, the metabolic connection of micro-organisms is essential for the mineralization of organic matter. Methanogenic conversion occurs by a stepwise degradation process consisting of hydrolysis, fermentation, syntrophic oxidation and methanogenesis. Acetate is the most significant precursor of $\mathrm{CH}_{4}$ and/or $\mathrm{CO}_{2}$ within this process (Lovley \& Klug, 1982; Mountfort \& Asher, 1978; Rothfuss \& Conrad, 1993; Sansone \& Martens, 1981). Two genera of the methanogenic archaea, 
Methanosarcina and Methanosaeta (formerly called Methanothrix), have been determined to be aceticlastic (Jetten et al., 1992). In addition, syntrophic acetate oxidizers associated with hydrogenotrophic methanogens are involved in the degradation of acetate. This syntrophic activity has been found in both natural and engineered environments (Nüsslein et al., 2001; Petersen \& Ahring, 1991; Schnürer et al., 1999; Shigematsu et al., 2004).

Anaerobic digesters have been widely used for the treatment of industrial and municipal wastewaters (Lettinga, 1995; Speece, 1996). Up to now, microbial communities that drive anaerobic digestion have been investigated using a variety of molecular approaches (Narihiro \& Sekiguchi, 2007; Talbot et al., 2008). Using isotope-tracing assays, syntrophic oxidation and aceticlastic cleavage have been identified as the main mechanisms of acetate degradation in anaerobic digesters (Ahring, 1995; Karakashev et al., 2006; Petersen \& Ahring, 1991). A low concentration of acetate and the absence of the aceticlastic methanogen Methanosaeta have been reported to be crucial environmental factors for the occurrence of syntrophic acetate oxidation. Furthermore, recent molecular studies have indicated that syntrophic oxidation may play an important role in the activity of thermophilic anaerobic digesters (Goberna et al., 2009; Hori et al., 2006a; Krakat et al., 2010; Ryan et al., 2010). Yet very little is known about the genetic diversity of the micro-organisms involved. Only five syntrophic acetate-oxidizing bacteria have been isolated to date: the strain AOR, Clostridium ultunense, Thermacetogenium phaeum, Thermotoga lettingae and Syntrophaceticus schinkii (Balk et al., 2002; Hattori et al., 2000; Lee \& Zinder, 1988b; Schnürer et al., 1996; Westerholm et al., 2010). Also, the complete lack of ecological biomarkers for acetate-oxidizing syntrophs has greatly limited our understanding of these micro-organisms.

Which metabolic pathway is associated with syntrophic oxidation of acetate? Biochemical studies have demonstrated that the homoacetogenic bacterium T. phaeum may drive the acetyl-CoA pathway reversibly for syntrophic acetate oxidation (Hattori et al., 2005; Hattori, 2008). Likewise, other syntrophs isolated so far, the strain AOR and C. ultunense, could use the acetyl-CoA pathway for both homoacetogenic and acetotrophic reactions (Lee \& Zinder, 1988c; Schnürer et al., 1997). Based on these findings, it is expected that syntrophic oxidation depends at least partially on the driving force of the acetyl-CoA pathway (Zinder, 1994). Formyltetrahydrofolate synthetase (FTHFS) is one of the key enzymes for reductive acetogenesis, and the coding gene has been used as a molecular biomarker for studying the ecology and activity of functional consortia (Henderson et al., 2010; Leaphart et al., 2003; Lovell \& Leaphart, 2005; Pester \& Brune, 2006). T. phaeum employs almost the same enzymic apparatus in both syntrophic acetate oxidation and reductive acetogenesis; the FTHFS enzyme is expressed more highly during syntrophic growth than during chemoheterotrophic growth (Hattori et al., 2005). Therefore, FTHFS likely engages in not only reductive acetogenesis but also syntrophic acetate oxidation.

Thermodynamics indicate that the amount of energy synthesized from reductive acetogenesis $\left(\Delta G^{0 \prime}=-104.6 \mathrm{~kJ}\right.$ $\mathrm{mol}^{-1}$ ) is lower than that synthesized from hydrogenotrophic methanogenesis $\left(\Delta G^{0 \prime}=-135.6 \mathrm{~kJ} \mathrm{~mol}^{-1}\right)$; the Gibbs free energy values are calculated under standard conditions (298 K, pH 7, solute at $1 \mathrm{M}$, gases at $10^{5} \mathrm{~Pa}$ ) (Lee \& Zinder, 1988a). Furthermore, thermophilic temperatures are recognized as being unfavourable for reductive acetogenesis (Akutsu et al., 2009). Theoretically, hydrogenotrophic methanogens can metabolize $\mathrm{H}_{2}$ and $\mathrm{CO}_{2}$ more under substrate-limiting thermophilic conditions than can homoacetogens (Zehnder \& Stumm, 1988). The objective of this study was to investigate the activity and composition of potentially acetate-oxidizing syntrophs, with a focus on reversed reductive acetogenesis, using a combination approach of $\left[{ }^{13} \mathrm{C}\right]$ acetate flux measurement and expression profiling of the bacterial FTHFS gene.

\section{METHODS}

Operation of the thermophilic anaerobic digester. A starter culture was obtained from a thermophilic anaerobic digester treating garbage slurry from restaurants (Hori et al., 2006b; Ueno et al., 2001). The methanogenic microbiota were cultivated at $55^{\circ} \mathrm{C}$ in a 2.41 stirred tank reactor (MDL-100, B. E. Marubishi) supplemented with synthetic wastewater at a dilution rate of 0.1 day $^{-1}$ [hydraulic retention time (HRT): 10 days]. The wastewater contained glucose $(1 \%, w / v)$ as sole carbon and energy source [organic loading rate (OLR): $400 \mathrm{mg}$ total organic carbon (TOC) $1^{-1} \mathrm{day}^{-1}$, and the composition was $\left(\mathrm{g} \mathrm{l}^{-1}\right): \mathrm{KH}_{2} \mathrm{PO}_{4}, 0.908 ; \mathrm{Na}_{2} \mathrm{HPO}_{4} .12 \mathrm{H}_{2} \mathrm{O}, 2.39$; $\mathrm{NH}_{4} \mathrm{Cl}, 0.5 ; \mathrm{MgCl}_{2} \cdot 6 \mathrm{H}_{2} \mathrm{O}, 0.18$; yeast extract (Difco), 2.0 and glucose, 10.0; as well as $10 \mathrm{ml}$ vitamin solution containing $\left(\mathrm{mg} \mathrm{l}^{-1}\right)$ : biotin, 2.0; folic acid, 2.0; pyridoxine $\mathrm{HCl}, 10.0$; thiamine $\mathrm{HCl}, 5.0$; riboflavin, 5.0; nicotinic acid, 5.0; DL-calcium pantothenate, 5.0; vitamin $\mathrm{B}_{12}, 0.1 ; p$-aminobenzoic acid, 5.0 and lipoic acid, 5.0. The minerals were injected directly into the reactor once per 2 days at the following final concentrations $\left(\mathrm{mg} \mathrm{l}^{-1}\right): \mathrm{FeSO}_{4} \cdot 7 \mathrm{H}_{2} \mathrm{O}, 5.53$; $\mathrm{CoCl}_{2} \cdot 6 \mathrm{H}_{2} \mathrm{O}, 0.48 ; \mathrm{ZnCl}_{2}, 0.67 ; \mathrm{CaCl}_{2} .2 \mathrm{H}_{2} \mathrm{O}, 0.59 ; \mathrm{CuCl}_{2} \cdot 2 \mathrm{H}_{2} \mathrm{O}$, $0.16 ; \mathrm{MnCl}_{2} .4 \mathrm{H}_{2} \mathrm{O}, 2.02 ; \mathrm{H}_{3} \mathrm{BO}_{4}, 0.063 ; \mathrm{Na}_{2} \mathrm{MoO}_{4} .2 \mathrm{H}_{2} \mathrm{O}, 0.0045$; $\mathrm{NiCl}_{2} \cdot 6 \mathrm{H}_{2} \mathrm{O}, 0.65$. The $\mathrm{pH}$ was kept at 7.1 by automatic titration with $5 \mathrm{M} \mathrm{NaOH}$. The reactor was operated stably under steady-state conditions for more than 3 months with little accumulation of volatile fatty acids (VFAs). The reproducibility of reactor performance and microbial community structure was confirmed by the operation of parallel reactors. The analytical methods for monitoring reactor performance have been described previously (Hori et al., 2006a). Briefly, gas production was measured on the basis of liquid displacement. The concentration of VFAs was determined using an HPLC (Alliance 2695, Waters) equipped with an OApak-A column (Tosoh) and a photodiode array (2996, Waters). Total carbon (TC) and inorganic carbon (IC) were determined using a total carbon analyser (TOC-V CSN, Shimadzu). Total suspended solids (SS) were determined as described previously (Ueno et al., 2001). The culture sample removed from the anaerobic digester under steady-state conditions was used for flux measurement and microbial community analyses.

Flux measurement using batch cultivation with ${ }^{13} \mathrm{C}$-labelled acetate. The batchwise gas generation test with ${ }^{13} \mathrm{C}$-labelled acetate reported by Shigematsu et al. (2004) was improved to take into 
account the effect of the background pool of dissolved IC on the degradation pathway of acetate. Briefly, $15 \mathrm{ml}$ methanogenic culture was removed from the bioreactor and anaerobically placed in $25 \mathrm{ml}$ serum vials, which were then sealed with butyl rubber septa. The headspace of incubation vials was flushed with $\mathrm{N}_{2}$. The methanogenic slurry was supplemented with $\left[1-{ }^{13} \mathrm{C}\right]$ sodium acetate, $\left[2-{ }^{13} \mathrm{C}\right]$ sodium acetate, or $\left[\mathrm{U}-{ }^{13} \mathrm{C}\right]$ sodium acetate (99 atom \%, Sigma-Aldrich) at a final concentration of $0.5 \mathrm{mM}$. Each treatment was performed in duplicate with shaking at $55{ }^{\circ} \mathrm{C}$. After the supplemented $\left[{ }^{13} \mathrm{C}\right]$ acetate had mostly been converted ( 2 days of incubation), the headspace $\mathrm{CH}_{4}$ and $\mathrm{CO}_{2}$ were analysed by a GC-MS (GC17A-QP5050, Shimadzu) equipped with a CP-PoraPLOT Q column $(25 \mathrm{~m} \times 0.32 \mathrm{~mm}$, GL Science). Helium gas was used as carrier at a flow rate of $1.5 \mathrm{ml}$ $\min ^{-1}$. The column temperature was $35^{\circ} \mathrm{C}$. The $\mathrm{CO}_{2}$ assay revealed a high background production of unlabelled $\mathrm{CO}_{2}$ during the incubation, which made it impossible to precisely determine fractions of ${ }^{13} \mathrm{CO}_{2}$ and ${ }^{12} \mathrm{CO}_{2}$ from $\left[{ }^{13} \mathrm{C}\right]$ acetate. In the $\mathrm{CH}_{4}$ analysis using the selected ion monitoring (SIM) mode, a peak at $\mathrm{m} / z 17$ was regarded as a fragment ion for ${ }^{13} \mathrm{CH}_{4}$. A peak at $\mathrm{m} / z 15$ included the signals from ${ }^{12} \mathrm{CH}_{3}^{+}$and ${ }^{13} \mathrm{CH}_{2}^{+}$. On the basis of the MS spectrum of ${ }^{13} \mathrm{CH}_{4}$, the signal from ${ }^{13} \mathrm{CH}_{2}^{+}$represented $22.85 \%$ of the peak intensity of $\mathrm{m} /$ $z 17$ (data not shown). The calculated signal intensity of ${ }^{13} \mathrm{CH}_{2}^{+}$was subtracted from the peak intensity of $\mathrm{m} / z 15$; this corrected signal that indicates ${ }^{12} \mathrm{CH}_{3}^{+}$was regarded as fragment ion for ${ }^{12} \mathrm{CH}_{4}$. The average peak intensities of these fragment ions for duplicate experiments are presented. The production of $\mathrm{CH}_{4}$ and/or $\mathrm{CO}_{2}$ from acetate is a direct consequence of the cleavage pathway; in aceticlastic cleavage the carbon of the methyl group in acetate is degraded to $\mathrm{CH}_{4}$ and that of the carboxyl group is degraded to $\mathrm{CO}_{2}$, whereas in syntrophic acetate oxidation the carbons of both the groups in acetate are converted to $\mathrm{CO}_{2}$ (Ferry, 1993; Zinder \& Koch, 1984). In addition, the background pool of dissolved IC affects $\mathrm{CH}_{4}$ production via the syntrophic pathway; ${ }^{13} \mathrm{CO}_{2}$ formed from syntrophic oxidation of $\left[{ }^{13} \mathrm{C}\right]$ acetate is diluted in the background IC pool present in anaerobic digesters. Taken together, the ratio of ${ }^{13} \mathrm{CH}_{4}$ to ${ }^{12} \mathrm{CH}_{4}$ generated from the supplemented $\left[{ }^{13} \mathrm{C}\right]$ acetate was used for quantifying the degree of syntrophic acetate oxidation. A schematic view of the procedure used to determine the mass balance of ${ }^{13} \mathrm{CH}_{4}$ and ${ }^{12} \mathrm{CH}_{4}$ is shown in Fig. 1, in which $100 \mu \mathrm{M}{ }^{13} \mathrm{CH}_{3} \mathrm{COOH}$ was degraded via aceticlastic methanogenesis $(50 \%)$ and syntrophic oxidation (50\%), and the background pool of dissolved IC was $900 \mu \mathrm{M}$.

Extraction of total nucleic acids from the digester microbiota. Total nucleic acids were extracted from the methanogenic culture using a direct lysis procedure, including bead beating (Noll et al., 2005). Total DNA was prepared by digestion with RNase (type II-A, Sigma-Aldrich) and total RNA was obtained by DNase digestion (RQ1, Promega). The DNA was used for the archaeal 16S rRNA genebased and FTHFS gene-based analyses. The RNA was used for transcriptional assay of the FTHFS gene.

PCR and RT-PCR. PCR and RT-PCR were conducted for terminal RFLP (T-RFLP) (Liu et al., 1997) and clone library analyses. The primer set Ar109f/Ar912rt was used for the archaeal 16S rRNA gene fingerprinting (Lueders \& Friedrich, 2002). This primer set offers good coverage of the 16S rRNA genes from almost all methanogenic archaea, including cultured aceticlastic methanogens. The primer set for the FTHFS gene has been described elsewhere (Lovell \& Leaphart, 2005). For T-RFLP, primer Ar912rt and the FTHFS-targeted forward primer were covalently labelled with 6-carboxyfluorescein (FAM). PCR amplification was performed using AmpliTaqGold (Applied Biosystems). The thermal conditions of the 16S rRNA gene-based PCR were as described previously (Hori et al., 2007), except that a total of 20 cycles were employed. The thermal conditions of the FTHFS gene-based PCR have been described elsewhere (Lovell \& Leaphart, 2005). RT-PCR of the FTHFS-coding mRNA was carried out using SuperScript III One-Step RT-PCR with Platinum Taq

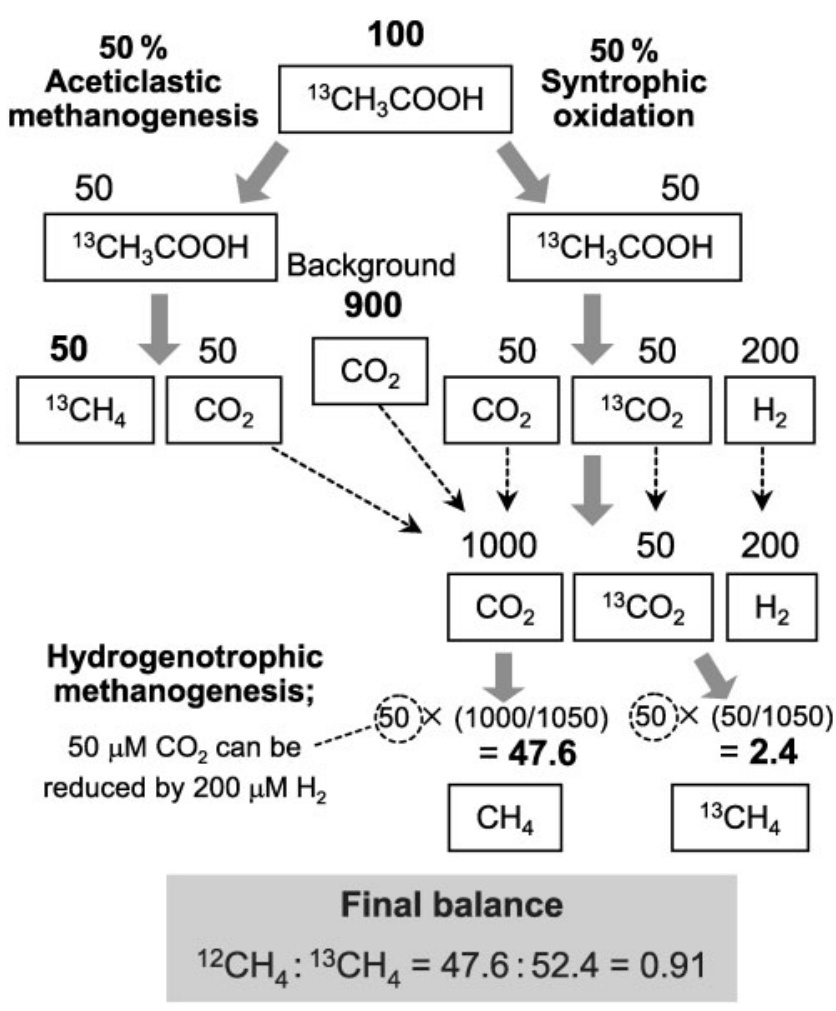

Fig. 1. Schematic view of the method used to determine the mass balance of ${ }^{13} \mathrm{CH}_{4}$ and ${ }^{12} \mathrm{CH}_{4}$. One situation is shown: $100 \mu \mathrm{M}$ ${ }^{13} \mathrm{CH}_{3} \mathrm{COOH}$ was degraded via aceticlastic methanogenesis $(50 \%)$ and syntrophic oxidation (50\%), and the background pool of dissolved IC was $900 \mu \mathrm{M}$.

(Invitrogen). The thermal conditions of the FTHFS RT-PCR were as reported elsewhere (Pester \& Brune, 2006) with slight modifications: we conducted reverse transcription at $55^{\circ} \mathrm{C}$ for $45 \mathrm{~min}$ and employed 25 cycles in the standard PCR program, during which the annealing temperature was $55{ }^{\circ} \mathrm{C}$. A high temperature $\left(55^{\circ} \mathrm{C}\right)$ for the reversetranscription and annealing steps was used to avoid the formation of non-specific amplicons. The cycle number used here was the minimal number needed to obtain a sufficient amount of the RT-PCR amplicons for further examination. RT-PCR without reverse transcriptase was used to confirm the absence of DNA contamination in the transcriptional assay.

T-RFLP. The PCR and RT-PCR amplicons were purified by a Wizard SV Gel and PCR Clean-Up system (Promega). The archaeal 16S rRNA gene fragments were digested with the restriction enzyme TaqI (New England Biolabs). The FTHFS gene amplicons were digested simultaneously with MspI and RsaI (New England Biolabs). The digests were suspended in Hi-Di formamide (Applied Biosystems) containing GeneScan 500 or 1000 (Applied Biosystems) as the internal size standard. Prior to electrophoresis, the mixture was denatured at $95{ }^{\circ} \mathrm{C}$ for $3 \mathrm{~min}$ and then cooled on ice. Terminal restriction fragments (T-RFs) were separated by electrophoresis with a 3130xl genetic analyser (Applied Biosystems), and the T-RF length was determined by comparison with the size standard. T-RFLP profiles were analysed on the basis of the peak size and height using GeneMapper software, version 3.7 (Applied Biosystems). A T-RF with more than $1 \%$ abundance to the total peak height was recognized as being distinct (Dunbar et al., 2001). T-RFLP was conducted for the 
same DNA or RNA, and the preparation of T-RF samples was performed in triplicate. A representative profile of the triplicate $\mathrm{T}$ RFLP analyses was used to present a consensus result.

Clone library analysis. The PCR and RT-PCR products were purified using a QIAquick PCR purification kit (Qiagen) and then subjected to ligation with a pGEM-T Easy vector (Promega). The ligation mixture was used to transform Escherichia coli JM109 supercompetent cells (TOYOBO) according to the manufacturer's protocol. We randomly selected 29 clones for the archaeal 16S rRNA gene, 43 clones for the FTHFS gene and 46 clones for the FTHFS gene transcripts. The gene segments were sequenced using a BigDye Terminator v3.1 Cycle Sequencing kit (Applied Biosystems) and a 3130xl Genetic Analyzer (Applied Biosystems). The absence of chimeric structure was checked by phylogenetically analysing the terminal stretches at the $5^{\prime}$ and $3^{\prime}$ ends (Ludwig et al., 1998, 2004). For the FTHFS-based library, clones with $>93 \%$ amino acid sequence identity were treated as belonging to an identical phylotype and clones with at least $99.5 \%$ gene sequence identity were defined as having the same genotype (Pester \& Brune, 2006). The closest cultured representative was determined by comparing the gene sequence with those in the DDBJ nucleotide sequence database using the BLAST program. A representative clone from each genotype was sequenced from both strands, and the obtained sequences were deposited in the database.

PCR and direct sequencing of the FTHFS homologue from $T$. phaeum. T. phaeum (DSM 12270), a thermophilic bacterium that has been positively identified as a syntrophic acetate oxidizer, was obtained from the Deutsche Sammlung von Mikroorganismen und Zellkulturen (DSMZ) culture collection. This bacterium was cultivated under appropriate conditions. DNA extraction from the cell culture and PCR amplification of the FTHFS homologue are described above. The FTHFS gene-based PCR yielded the expected $\sim 1.1 \mathrm{~kb}$ gene fragment. The PCR product was purified using a QIAquick PCR purification kit (Qiagen). The DNA segment was used as a template for direct sequencing from both strands with the BigDye Terminator v3.1 Cycle Sequencing kit and a 3130xl Genetic Analyzer.

Phylogenetic analysis of the FTHFS genes. The reference and obtained sequences of the FTHFS amino acids were aligned using CLUSTAL_X software, version 2.00 (Thompson et al., 1997). After the alignment had been corrected manually (e.g. the alignment gaps were ruled out) on the basis of conserved or functionally important areas of FTHFS (Henderson et al., 2010; Leaphart et al., 2003; Lovell \& Leaphart, 2005), phylogenetic trees were constructed by the neighbour-joining and maximum-likelihood methods using PHYLIP software, version 3.68 (Felsenstein, 2005), and by the neighbour-joining, maximumparsimony and maximum-evolution methods using MEGA software, version 4.0.2 (Kumar et al., 2008; Tamura et al., 2007). Use of the different tree construction algorithms resulted in similar dendrogram topology. Bootstrap values were obtained from 1000 replications.

\section{RESULTS}

\section{Reactor performance and archaeal population in the anaerobic digester}

Under steady-state conditions during the operation of the thermophilic anaerobic digester, acetate concentrations were $0.49-0.60 \mathrm{mmol} \mathrm{l}^{-1}$, and other VFAs, such as propionate and butyrate, were not detected. The TOC and IC concentrations of the culture supernatant were approximately 110 and $560 \mathrm{mg}$ $\mathrm{l}^{-1}$, respectively. The gas production rate was around $580 \mathrm{ml}$ day ${ }^{-1} ; \mathrm{CH}_{4}$ represented more than $80 \%$ of the gas produced.
The amount of total SS as the cell mass in the culture was determined to be $1.34 \mathrm{~g} \mathrm{l}^{-1}$. From these chemical parameters, it was determined that approximately $70 \%$ of the supplemented carbon within synthetic wastewater was recovered as the microbial cells and metabolites (e.g. VFAs and gases).

The archaeal population was examined by $16 \mathrm{~S}$ rRNA genebased T-RFLP. A total of three peaks were detected in the profile. An $84 \mathrm{bp}$ T-RF accounted for $91 \%$ of the total peak height. A T-RF of $92 \mathrm{bp}$ accounted for $8 \%$ of the total. An archaeal clone library was constructed to phylogenetically characterize these T-RFs. The most frequently detected clone ( $93 \%$ of the total) was related to the hydrogenotrophic methanogen Methanoculleus thermophilus (AJ862839; $100 \%$ sequence identity), which corresponded to the $84 \mathrm{bp}$ T-RF. The remaining clones in the library were affiliated with the hydrogenotrophic methanogen Methanothermobacter thermautotrophicus (AY196660; $99 \%$ sequence identity), corresponding to the 92 bp T-RF. In the T-RFLP profile, the $187 \mathrm{bp}$ T-RF, corresponding to the aceticlastic methanogen Methanosarcina sp., was detected but represented less than $1 \%$ relative abundance. The long operation for over 1 year of the anaerobic digester under steady-state conditions resulted in a small increase of Methanosarcina sp. to $\sim 5 \%$ of the total archaeal population (data not shown).

\section{Acetate degradation pathway driven by the digester microbiota}

In order to characterize the acetate degradation pathway in the anaerobic digester, batchwise cultivation of the slurry micro-organisms was carried out using three different forms of ${ }^{13} \mathrm{C}$-labelled acetate at a concentration of $0.5 \mathrm{mM}$ (Table 1). Fractions of ${ }^{13} \mathrm{CH}_{4}$ and ${ }^{12} \mathrm{CH}_{4}$ produced from $\left[1-{ }^{13} \mathrm{C}\right]$ acetate or $\left[2-{ }^{13} \mathrm{C}\right]$ acetate were determined using the GC-MS SIM method. Amendment with $\left[\mathrm{U}^{13}{ }^{13} \mathrm{C}\right]$ acetate was done to assay the background production of unlabelled $\mathrm{CH}_{4}$. The background pool of dissolved IC was $560 \mathrm{mg} \mathrm{l}^{-1}$ (i.e. $46.7 \mathrm{mM}$ ), which was taken into account for the calculation of the ratio of ${ }^{13} \mathrm{CH}_{4}$ and ${ }^{12} \mathrm{CH}_{4}$ produced from $\left[{ }^{13} \mathrm{C}\right]$ acetate. In the $\left[1-{ }^{13} \mathrm{C}\right]$ acetate treatment, ${ }^{13} \mathrm{CH}_{4}:{ }^{12} \mathrm{CH}_{4}$ was 0.151 , indicating that $13.1 \%$ of methane production from acetate was mediated via the syntrophic oxidative pathway. On the other hand, ${ }^{12} \mathrm{CH}_{4}:{ }^{13} \mathrm{CH}_{4}$ was 0.269 in the $\left[2{ }^{13} \mathrm{C}\right]$ acetate treatment, which indicates that $21.3 \%$ of the supplemented acetate was degraded by syntrophic oxidation. Overall, syntrophic acetate oxidation accounted for $13.1-21.3 \%$ of the total acetate degradation in the anaerobic digester.

\section{Expression profile of the FTHFS genes using mRNA and DNA fingerprinting}

The expected fragment (size: approximately $1.1 \mathrm{~kb}$ ) of the FTHFS gene was successfully amplified using RT-PCR and PCR with total RNA and DNA, respectively, extracted from the digester slurry. T-RFLP of the FTHFS genes and transcripts was conducted (Fig. 2). The pattern of the 
Table 1. Distribution of ${ }^{13} \mathrm{CH}_{4}$ and ${ }^{12} \mathrm{CH}_{4}$ converted from three different forms of $\left[{ }^{13} \mathrm{C}\right]$ acetate

\begin{tabular}{|c|c|c|c|c|c|c|}
\hline \multirow[t]{3}{*}{ Substrate ${ }^{\star}$} & \multicolumn{4}{|c|}{ Peak intensity } & \multirow{3}{*}{$\begin{array}{c}\text { Ratio of }{ }^{13} \mathrm{CH}_{4} \\
\text { to }{ }^{12} \mathrm{CH}_{4} \dagger\end{array}$} & \multirow{3}{*}{$\begin{array}{c}\text { Syntrophic } \\
\text { acetate } \\
\text { oxidation (\%) }\end{array}$} \\
\hline & \multicolumn{3}{|c|}{$m / z 15\left({ }^{12} \mathrm{CH}_{4}\right)$} & \multirow[t]{2}{*}{$m / z 17\left({ }^{13} \mathrm{CH}_{4}\right)$ actual } & & \\
\hline & Actual & $\begin{array}{c}{ }^{13} \mathrm{CH}_{2}^{+} \\
\text {subtracted } \neq\end{array}$ & $\begin{array}{l}\text { Background } \\
\text { subtracted } \S\end{array}$ & & & \\
\hline${ }^{13} \mathrm{CH}_{3}{ }^{12} \mathrm{COONa}$ & $2574258( \pm 110261) \|$ & 2453832 & 141791 & $527029( \pm 14883) \|$ & 0.269 & 21.3 \\
\hline${ }^{12} \mathrm{CH}_{3}{ }^{13} \mathrm{COONa}$ & $2718708( \pm 17938) \|$ & 2705138 & 393097 & $59387( \pm 5327) \|$ & 0.151 & 13.1 \\
\hline${ }^{13} \mathrm{CH}_{3}{ }^{13} \mathrm{COONa}$ & $2449741( \pm 52394) \|$ & 2312041 & & $602626( \pm 5085) \|$ & & \\
\hline
\end{tabular}

*The supplemented $\left[{ }^{13} \mathrm{C}\right]$ acetate was mostly converted to gaseous products.

$\dagger$ The values indicate ${ }^{12} \mathrm{CH}_{4}:{ }^{13} \mathrm{CH}_{4}$ for the $\left[2-{ }^{13} \mathrm{C}\right]$ acetate treatment and ${ }^{13} \mathrm{CH}_{4}:{ }^{12} \mathrm{CH}_{4}$ for the $\left[1-{ }^{13} \mathrm{C}\right]$ acetate treatment, which were used for quantifying the degree of syntrophic acetate oxidation.

¥The signal from ${ }^{13} \mathrm{CH}_{2}^{+}$represented $22.85 \%$ of the peak intensity of $\mathrm{m} / z 17$.

$\S$ Peak intensity at $\mathrm{m} / z 15$ from $\left[\mathrm{U}_{-}{ }^{13} \mathrm{C}\right]$ sodium acetate was regarded as arising from the background production of unlabelled $\mathrm{CH}_{4}$.

IIAll values are averages from duplicate experiments. Values in parentheses represent the variations between the duplicate measurements (i.e. the range).

mRNA fingerprint was different from the DNA pattern, indicating that specific lineages expressed the FTHFS genes. In both the profiles, a T-RF of $138 \mathrm{bp}$ in length was predominant, followed by a 329 bp T-RF. Furthermore, a few peaks, such as that corresponding to a $319 \mathrm{bp} \mathrm{T-RF}$, were detected by the mRNA profiling but not by the DNA analysis. Phylogenetic identification of the T-RFs was performed using the mRNA- and DNA-based clone analyses (Table 2). A total of nine FTHFS phylotypes were obtained from these two libraries. The composition of the mRNA library was quite distinct from that of the DNA library. Phylotype I was a dominant constituent of both the mRNA library and the DNA library, accounting for 32 and $39 \%$ of the total clones, respectively. The expected T-RF length was $138 \mathrm{bp}$, which corresponded to the primary peak in the T-RFLP fingerprints (Fig. 2). The phylotype was only distantly related to cultured representatives. The sequence identity of amino acids was $76.0-77.1 \%$ to the homoacetogen Moorella thermoacetica (Drake \& Daniel, 2004). Phylotypes II and III were observed in the mRNA library, whereas no clone belonging to these phylotypes was detected in the DNA library. The T-RF size of phylotype III was predicted to be $319 \mathrm{bp}$, and only the mRNA T-RFLP detected this phylotype. The phylotype was novel, and the sequence identity of amino acids was $79.0 \%$ to the homoacetogen Oxobacter pfennigii (formerly Clostridium pfennigii) (Krumholz \& Bryant, 1985). Phylotype IV, corresponding to the major peak of $329 \mathrm{bp}$ in the T-RFLP profiles, was detected in both the mRNA library and the DNA library. A small portion (2\%) of the mRNA library originated from phylotype V. Phylotypes VI to IX were recovered only from the DNA library.

\section{Relationship of the FTHFS phylotypes to cultivated acetate-oxidizing syntrophs}

The FTHFS gene homologue from the isolated acetateoxidizing syntroph T. phaeum was determined using PCR and direct sequencing. The FTHFS gene sequence from $T$. phaeum was completely matched with that from phylotype $\mathrm{V}$, one of the phylotypes that transcribed the FTHFS genes, which indicates the phylogenetic identity of these microorganisms. A phylogenetic tree of the FTHFS amino acids was constructed to characterize the relationship among FTHFS genes obtained from the digester microbiota (i.e. phylotypes I-IX), T. phaeum and reference micro-organisms (including homoacetogens and non-homoacetogens) (Fig. 3). Phylotypes I-V that transcribed the FTHFS genes were all affiliated with phylogenetic branches that mainly consist of true homoacetogenic bacteria. In earlier reports (Leaphart \& Lovell, 2001; Leaphart et al., 2003; Lovell \& Leaphart, 2005), phylogenetic placement of the FTHFS amino acids was used to determine whether or not these bacteria are homoacetogens. However, it has also been reported that the FTHFS gene might be subject to lateral gene transfer (Salmassi \& Leadbetter, 2003). More recently, Henderson et al. (2010) have proposed a 'homoacetogen similarity' (HS) score based on the conserved FTHFS residues that are diagnostic for homoacetogens. The characteristic amino acids in the homoacetogen FTHFS were improved according to the FTHFS sequence determined from the homoacetogen $T$. phaeum. The HS scores from phylotypes I, II, III and IV that expressed the FTHFS genes were 88, 85, 98 and $79 \%$, respectively (Fig. 3). These HS scores were rather higher than those from phylotypes VI-IX (i.e. 53-75\%) that did not transcribe the FTHFS genes.

\section{DISCUSSION}

In this study, we investigated the metabolic activity and genetic composition of potentially acetate-oxidizing syntrophs, which are responsible for reversed reductive acetogenesis, in a thermophilic anaerobic digester. Applying 


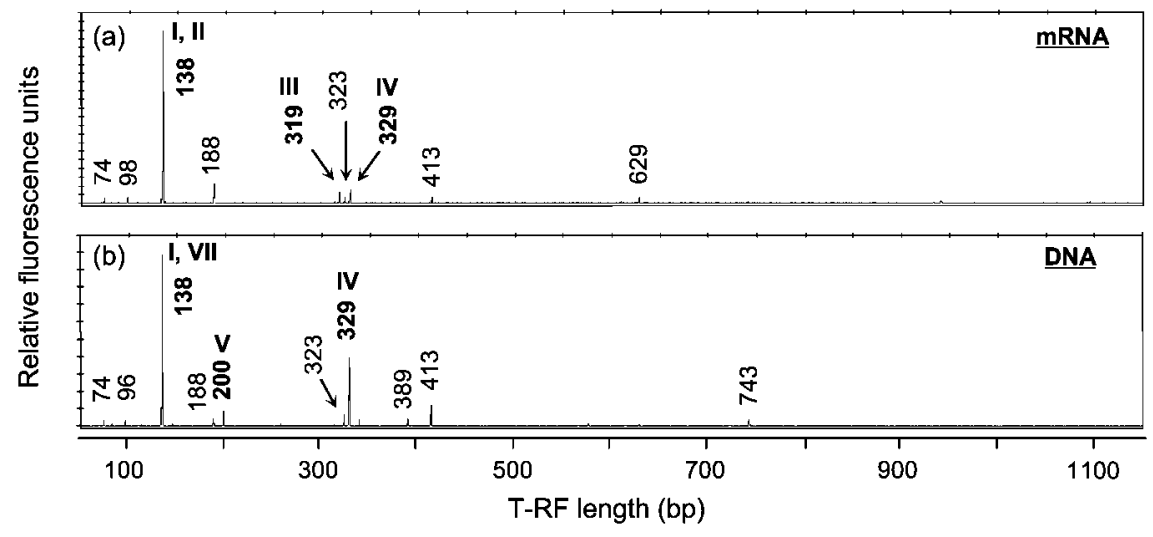

Fig. 2. Expression profile of the bacterial FTHFS genes in the bioreactor as revealed by T-RFLP. (a) Profile of the gene transcripts; (b) profile of the genes. T-RFs with $>1 \%$ abundance with respect to the sum of all peak heights were considered distinct. The detected T-RF (bp) is given. T-RFs assignable to the FTHFS phylotypes in the clone libraries (see Table 2) are indicated by Roman numerals in bold type. T-RFLP was performed in triplicate, and a representative profile is shown.

${ }^{13} \mathrm{C}$-labelled acetate at an environmentally relevant concentration (i.e. $0.5 \mathrm{mM}$ ) and tracing the fate of the stable isotope using the GC-MS SIM method directly revealed that $13.1-$ $21.3 \%$ of methane production from acetate was mediated by syntrophic oxidation (Table 1). Two different treatments of $\left[1-{ }^{13} \mathrm{C}\right]$ acetate or $\left[2{ }^{13} \mathrm{C}\right]$ acetate resulted in similar ratios of syntrophic to non-syntrophic reactions. The percentage of acetate degradation mediated by the syntrophic oxidative pathway is consistent with data obtained elsewhere for other thermophilic processes (Karakashev et al., 2006; Petersen \&
Ahring, 1991). The remainder of acetate degradation might be due to aceticlastic cleavage by Methanosarcina sp., which has been detected as a minor archaeal population and expresses $16 \mathrm{~S}$ rRNA in the anaerobic digester (Akuzawa et al., 2011; Hori et al., 2006a).

Inorganic electron acceptors (e.g. nitrate, ferric iron and/or sulfate) were not supplied to the anaerobic digester as the main components of synthetic wastewater. Only a small amount of sulfate was added concurrently with the

Table 2. Frequency and relative abundance of the bacterial FTHFS phylotypes in clone libraries originating from mRNA and DNA

\begin{tabular}{|c|c|c|c|c|c|c|}
\hline \multirow[t]{2}{*}{ Phylotype $^{\star}$} & \multicolumn{2}{|c|}{ Number of clones } & \multirow[t]{2}{*}{ Expected T-RF (bp) $\dagger$} & \multirow[t]{2}{*}{ Genotype $\neq$} & \multicolumn{2}{|c|}{ Number of clones $\S$} \\
\hline & mRNA & DNA & & & mRNA & DNA \\
\hline \multirow[t]{4}{*}{ I } & 15 & 17 & 138 & G11 & 13 & 16 \\
\hline & & & & G12 & & 1 \\
\hline & & & & G13 & 1 & \\
\hline & & & & G14 & 1 & \\
\hline II & 4 & & 138 & G21 & 4 & \\
\hline III & 24 & & 319 & G31 & 24 & \\
\hline \multirow[t]{4}{*}{ IV } & 2 & 12 & 329 & G41 & 2 & 7 \\
\hline & & & & G42 & & 3 \\
\hline & & & & G43 & & 1 \\
\hline & & & & G44 & & 1 \\
\hline V & 1 & 8 & 200 & G51 & 1 & 8 \\
\hline VI & & 2 & 117 & G61 & & 2 \\
\hline VII & & 2 & 138 & G71 & & 2 \\
\hline VIII & & 1 & 114 & G81 & & 1 \\
\hline IX & & 1 & 150 & G91 & & 1 \\
\hline Sum & 46 & 43 & & & & \\
\hline
\end{tabular}

${ }^{*}$ Clones with $>93 \%$ amino acid sequence identity.

$\dagger$ Expected length (bp) of the T-RF generated from digestion with restriction enzymes MspI and RsaI.

\$Clones with at least $99.5 \%$ gene sequence identity.

$\S$ Distribution of the genotypes within each phylotype. 


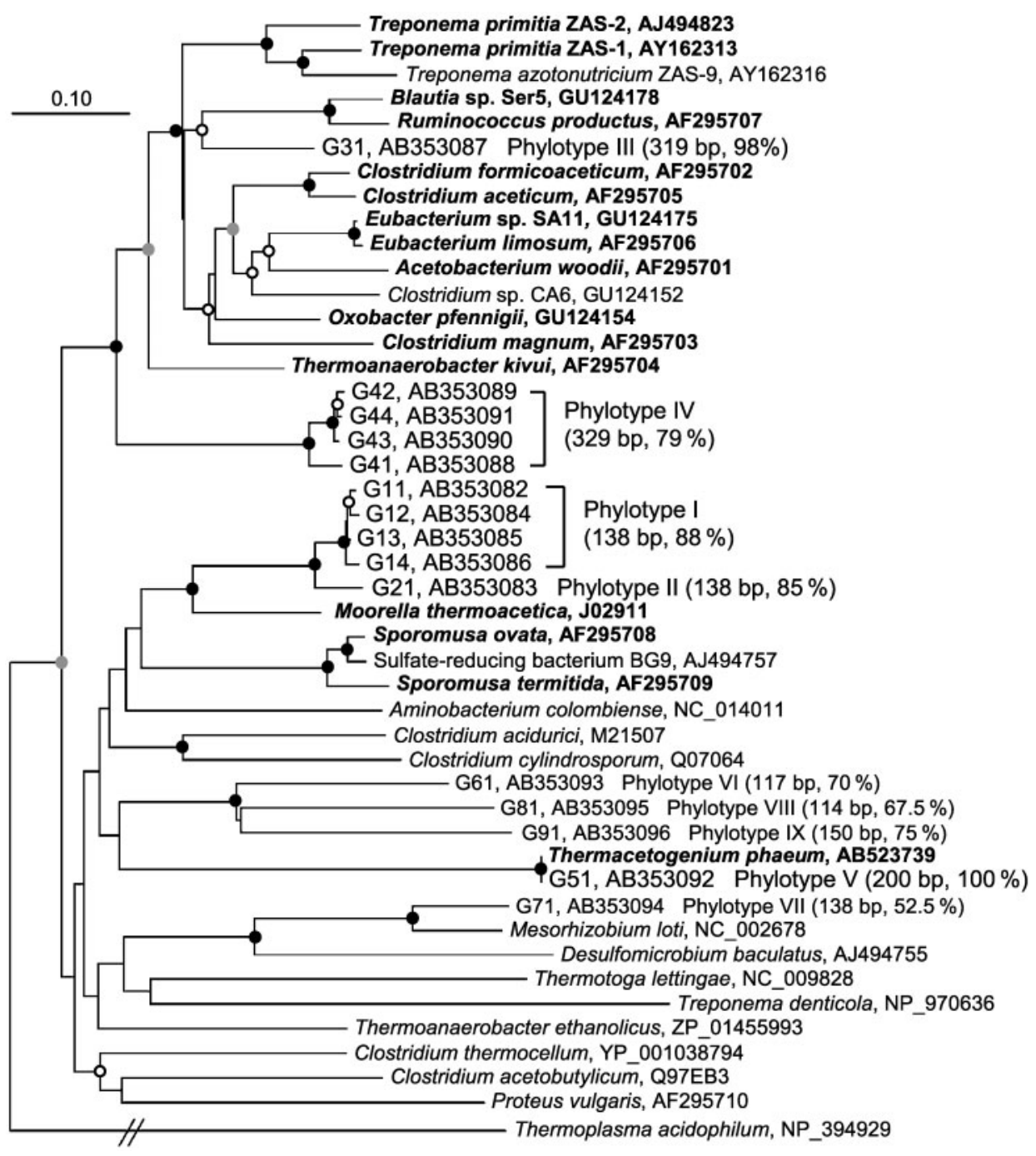

Fig. 3. Phylogenetic tree showing the relationship of FTHFS phylotypes I-IX. The expected T-RF lengths (bp) and the HS scores (expressed as percentages) of the obtained phylotypes are indicated in parentheses as follows: (T-RF length, HS score). The reference bacteria that have been positively identified as true homoacetogens are presented in bold type. The deduced amino acid sequences were used to construct the tree by the neighbour-joining method using PHYLIP software. No significant effect on the dendrogram topology using the other algorithms was seen. Bootstrap values were obtained from 1000 replications, and >90, 70-89 and 50-69\% are indicated by black, grey and open circles, respectively. Bar, $10 \%$ sequence divergence. GenBank accession numbers of the reference sequences are shown.

supplementation of mineral elements, but the reduction product $\mathrm{H}_{2} \mathrm{~S}$ was not detectable in the gaseous phase of the reactor operated. VFAs were mostly depleted in the bioreactor. Because the concentration of VFAs has been reported to be positively correlated with the concentration of dissolved $\mathrm{H}_{2}$ (Cord-Ruwisch et al., 1997; Schink, 1997), the direct substrate $\mathrm{H}_{2}$ for homoacetogens and hydrogenotrophic methanogens might be turned over at a high rate. Homoacetogenic bacteria can utilize carbon monoxide as an electron donor to obtain reducing equivalents. Methoxylated compounds such as methanol are other possible substrates for homoacetogens. In this anaerobic digester, carbon monoxide and methoxylated compounds were never detected. Under these substrate-limiting thermophilic conditions, reversed reductive acetogenesis (i.e. syntrophic acetate oxidation) is considered to occur preferentially with respect to reductive acetogenesis. It has been reported that thermophilic temperatures are unfavourable for reductive acetogenesis (Akutsu et al., 2009), and that reversed reductive acetogenesis functions to degrade acetate under thermophilic and methanogenic conditions (Ryan et al., 2010), which supports the hypothesis that reversed reductive acetogenesis, rather than reductive acetogenesis, was the dominant pathway in our anaerobic digester. Taken together, the FTHFS transcription in this study is implicated as the activity of reversed 
reductive acetogenesis. It has been demonstrated that the acetyl-CoA pathway also functions in acetate assimilation in a broad range of bacteria such as acetogens and sulfate reducers (Drake, 1994), and thereby FTHFS expression can reflect the outgrowth of such bacteria. However, in this study, the FTHFS genes were transcribed by specific phylotypes (e.g. I and III) (Fig. 2, Table 2). The abundant population of the FTHFS phylotypes did not necessarily transcribe the FTHFS genes, which strongly suggests that FTHFS expression was not accounted for by assimilative metabolism.

The archaeal 16S rRNA gene analyses revealed the dominance of the hydrogenotrophic methanogens Methanoculleus thermophilus and Methanothermobacter thermautotrophicus. These methanogens were possibly fuelled by $\mathrm{H}_{2}$ produced by fermentative degradation of glucose, the sole substrate during the reactor operation. In addition, from the framework determined by ${ }^{13} \mathrm{C}$ flux measurement, these methanogens were possible scavengers of $\mathrm{H}_{2}$ produced by syntrophic acetate oxidation. Subsequently, the FTHFS expression profiling was able to identify active potentially acetate-oxidizing syntrophic bacteria. Interestingly, phylotypes I-IV (particularly I and III) that transcribed the FTHFS genes were predicted to be homoacetogenic bacteria according to the high HS score (Fig. 3). The results are considered reasonable because most syntrophic acetate oxidizers are also responsible for reductive acetogenesis (Hattori, 2008). Although the sulfate reducer Thermotoga lettingae (NC_009828) does not have homoacetogenic activity, it is capable of oxidizing acetate syntrophically with $\mathrm{H}_{2}$-scavenging methanogens (Balk et al., 2002). This bacterium might use a different oxidative pathway, such as the citric acid cycle, as shown in earlier biochemical studies (Gebhardt et al., 1983; Schauder et al., 1987; Thauer, 1988). In addition, it is also noteworthy that most of the phylotypes that expressed the FTHFS genes were not similar to the isolated homoacetogenic bacteria; only phylotype $\mathrm{V}$ was identical to the acetate-oxidizing syntroph T. phaeum. These results indicate that as-yet-unidentified or phylogenetically predicted homoacetogenic bacteria played a decisive role in syntrophic acetate oxidation under the steady-state conditions in the anaerobic digester.

T-RFLP and clone library analyses in the FTHFS expression profiling showed that phylotypes I and III transcribed the FTHFS genes (Fig. 2, Table 2). Here a degenerate primer set was used for RT-PCR amplification of the FTHFS-coding mRNA and thus we were not able to precisely estimate the expression level. Also, there was a discrepancy between the peak height in the T-RFLP profiles and the relative sequence abundance in the clone libraries; this might be caused by a toxic effect of the FTHFS gene amplicons on $E$. coli competent cells, as reported elsewhere (Henderson et al., 2010) and/or an insufficient number of the FTHFS gene clones obtained in this study. However, the complementary use of these two methods provided the same information in terms of the existence or nonexistence of the phylotypes detected. The expression characteristics of phylotypes I and III seemed to be distinct from each other. Phylotype III was detected in the mRNA profiles but not in the DNA profiles, suggesting that a minor population of phylotype III expressed the FTHFS gene. The ecophysiological details and niche differentiation of these phylotypes are presently unknown and require further investigation.

The results of this study demonstrate for the first time, to our knowledge, the functional activity and molecular ecology of potentially acetate-oxidizing syntrophs that are dependent on reversed reductive acetogenesis in the thermophilic anaerobic digester. The combination of ${ }^{13} \mathrm{C}$ flux measurement and expression profiling of the FTHFS genes indicates that the hitherto unidentified and phylogenetically presumed homoacetogens are involved in syntrophic oxidation of acetate. Direct identification of the active syntrophic acetate oxidizers by stable isotope probing will provide deeper insight into the microbial phylogeny and ecophysiology (Hori et al., 2007, 2010). The metabolic versatility and survival strategy of the newly identified bacteria should be addressed to clarify their physiological significance for the anaerobic digestion of organic matter.

\section{ACKNOWLEDGEMENTS}

We wish to thank Satoshi Hattori (Yamagata University) for his useful comments on this study. We gratefully acknowledge many helpful comments and suggestions from the anonymous reviewers and the Editor, which helped to improve our manuscript substantially.

\section{REFERENCES}

Ahring, B. K. (1995). Methanogenesis in thermophilic biogas reactors. Antonie van Leeuwenhoek 67, 91-102.

Akutsu, Y., Li, Y.-Y., Harada, H. \& Yu, H.-O. (2009). Effects of temperature and substrate concentration on biological hydrogen production from starch. Int J Hydrogen Energy 34, 25582566.

Akuzawa, M., Hori, T., Haruta, S., Ueno, Y., Ishii, M. \& Igarashi, Y. (2011). Distinctive responses of metabolically active microbiota to acidification in a thermophilic anaerobic digester. Microb Ecol 61, 595-605.

Balk, M., Weijma, J. \& Stams, A. J. (2002). Thermotoga lettingae sp. nov., a novel thermophilic, methanol-degrading bacterium isolated from a thermophilic anaerobic reactor. Int J Syst Evol Microbiol 52, 1361-1368.

Cord-Ruwisch, R., Mercz, T. I., Hoh, C.-Y. \& Strong, G. E. (1997). Dissolved hydrogen concentration as an on-line control parameter for the automated operation and optimization of anaerobic digesters. Biotechnol Bioeng 56, 626-634.

Drake, H. L. (1994). Acetogenesis. New York: Chapman \& Hall.

Drake, H. L. \& Daniel, S. L. (2004). Physiology of the thermophilic acetogen Moorella thermoacetica. Res Microbiol 155, 869-883.

Dunbar, J., Ticknor, L. O. \& Kuske, C. R. (2001). Phylogenetic specificity and reproducibility and new method for analysis of terminal restriction fragment profiles of 16S rRNA genes from bacterial communities. Appl Environ Microbiol 67, 190-197. 
Felsenstein, J. (2005). PHYLIP (phylogeny inference package). Distributed by the author. Department of Genome Sciences, University of Washington, Seattle, WA.

Ferry, J. G. (1993). Fermentation of acetate. In Methanogenesis Ecology, Physiology, Biochemistry \& Genetics, pp. 304-334. Edited by J. G. Ferry. New York: Chapman \& Hall.

Gebhardt, A., Linder, D. \& Thauer, R. K. (1983). Anaerobic acetate oxidation to $\mathrm{CO}_{2}$ by Desulfobacter postgatei 2 . Evidence from ${ }^{14} \mathrm{C}$ labelling studies for the operation of the citric acid cycle. Arch Microbiol 136, 230-233.

Goberna, M., Insam, H. \& Franke-Whittle, I. H. (2009). Effect of biowaste sludge maturation on the diversity of thermophilic bacteria and archaea in an anaerobic reactor. Appl Environ Microbiol 75, 25662572.

Hattori, S. (2008). Syntrophic acetate-oxidizing microbes in methanogenic environments. Microbes Environ 23, 118-127.

Hattori, S., Kamagata, Y., Hanada, S. \& Shoun, H. (2000). Thermacetogenium phaeum gen. nov., sp. nov., a strictly anaerobic, thermophilic, syntrophic acetate-oxidizing bacterium. Int J Syst Evol Microbiol 50, 1601-1609.

Hattori, S., Galushko, A. S., Kamagata, Y. \& Schink, B. (2005). Operation of the CO dehydrogenase/acetyl coenzyme A pathway in both acetate oxidation and acetate formation by the syntrophically acetate-oxidizing bacterium Thermacetogenium phaeum. J Bacteriol 187, 3471-3476.

Henderson, G., Naylor, G. E., Leahy, S. C. \& Janssen, P. H. (2010). Presence of novel, potentially homoacetogenic bacteria in the rumen as determined by analysis of formyltetrahydrofolate synthetase sequences from ruminants. Appl Environ Microbiol 76, 2058-2066.

Hori, T., Haruta, S., Ueno, Y., Ishii, M. \& Igarashi, Y. (2006a). Dynamic transition of a methanogenic population in response to the concentration of volatile fatty acids in a thermophilic anaerobic digester. Appl Environ Microbiol 72, 1623-1630.

Hori, T., Haruta, S., Ueno, Y., Ishii, M. \& Igarashi, Y. (2006b). Direct comparison of single-strand conformation polymorphism (SSCP) and denaturing gradient gel electrophoresis (DGGE) to characterize a microbial community on the basis of 16S rRNA gene fragments. J Microbiol Methods 66, 165-169.

Hori, T., Noll, M., Igarashi, Y., Friedrich, M. W. \& Conrad, R. (2007). Identification of acetate-assimilating microorganisms under methanogenic conditions in anoxic rice field soil by comparative stable isotope probing of RNA. Appl Environ Microbiol 73, 101-109.

Hori, T., Müller, A., Igarashi, Y., Conrad, R. \& Friedrich, M. W. (2010). Identification of iron-reducing microorganisms in anoxic rice paddy soil by ${ }^{13} \mathrm{C}$-acetate probing. ISME J 4, 267-278.

Jetten, M. S. M., Stams, A. J. M. \& Zehnder, A. J. B. (1992). Methanogenesis from acetate: a comparison of acetate metabolism in Methanothrix soehngenii and Methanosarcina spp. FEMS Microbiol Rev 88, 181-198.

Karakashev, D., Batstone, D. J., Trably, E. \& Angelidaki, I. (2006). Acetate oxidation is the dominant methanogenic pathway from acetate in the absence of Methanosaetaceae. Appl Environ Microbiol 72, $5138-5141$.

Krakat, N., Westphal, A., Schmidt, S. \& Scherer, P. (2010). Anaerobic digestion of renewable biomass: thermophilic temperature governs methanogen population dynamics. Appl Environ Microbiol 76, 18421850.

Krumholz, L. R. \& Bryant, M. P. (1985). Clostridium pfennigii sp. nov. uses methoxyl groups of monobenzenoids and produces butyrate. Int J Syst Bacteriol 35, 454-456.
Kumar, S., Nei, M., Dudley, J. \& Tamura, K. (2008). MEGA: a biologistcentric software for evolutionary analysis of DNA and protein sequences. Brief Bioinform 9, 299-306.

Leaphart, A. B. \& Lovell, C. R. (2001). Recovery and analysis of formyltetrahydrofolate synthetase gene sequences from natural populations of acetogenic bacteria. Appl Environ Microbiol 67, 1392-1395.

Leaphart, A. B., Friez, M. J. \& Lovell, C. R. (2003). Formyltetrahydrofolate synthetase sequences from salt marsh plant roots reveal a diversity of acetogenic bacteria and other bacterial functional groups. Appl Environ Microbiol 69, 693-696.

Lee, M. J. \& Zinder, S. H. (1988a). Hydrogen partial pressures in a thermophilic acetate-oxidizing methanogenic coculture. Appl Environ Microbiol 54, 1457-1461.

Lee, M. J. \& Zinder, S. H. (1988b). Isolation and characterization of a thermophilic bacterium which oxidizes acetate in syntrophic association with a methanogen and which grows acetogenically on $\mathrm{H}_{2}-\mathrm{CO}_{2}$. Appl Environ Microbiol 54, 124-129.

Lee, M. J. \& Zinder, S. H. (1988c). Carbon monoxide pathway enzyme activities in a thermophilic anaerobic bacterium grown acetogenically and in a syntrophic acetate-oxidizing coculture. Arch Microbiol 150, 513-518.

Lettinga, G. (1995). Anaerobic digestion and wastewater treatment systems. Antonie van Leeuwenhoek 67, 3-28.

Liu, W. T., Marsh, T. L., Cheng, H. \& Forney, L. J. (1997). Characterization of microbial diversity by determining terminal restriction fragment length polymorphisms of genes encoding $16 \mathrm{~S}$ rRNA. Appl Environ Microbiol 63, 4516-4522.

Lovell, C. R. \& Leaphart, A. B. (2005). Community-level analysis: key genes of $\mathrm{CO}_{2}$-reductive acetogenesis. Methods Enzymol 397, 454-469.

Lovley, D. R. \& Klug, M. J. (1982). Intermediary metabolism of organic matter in the sediments of a eutrophic lake. Appl Environ Microbiol 43, 552-560.

Ludwig, W., Strunk, O., Klugbauer, S., Klugbauer, N., Weizenegger, M., Neumaier, J., Bachleitner, M. \& Schleifer, K. H. (1998). Bacterial phylogeny based on comparative sequence analysis. Electrophoresis 19, 554-568.

Ludwig, W., Strunk, O., Westram, R., Richter, L., Meier, H., Yadhukumar, Buchner, A., Lai, T., Steppi, S. \& other authors (2004). ARB: a software environment for sequence data. Nucleic Acids Res 32, 1363-1371.

Lueders, T. \& Friedrich, M. W. (2002). Effects of amendment with ferrihydrite and gypsum on the structure and activity of methanogenic populations in rice field soil. Appl Environ Microbiol 68, 24842494.

Mountfort, D. O. \& Asher, R. A. (1978). Changes in proportions of acetate and carbon dioxide used as methane precursors during the anaerobic digestion of bovine waste. Appl Environ Microbiol 35, 648654.

Narihiro, T. \& Sekiguchi, Y. (2007). Microbial communities in anaerobic digestion processes for waste and wastewater treatment: a microbiological update. Curr Opin Biotechnol 18, 273-278.

Noll, M., Matthies, D., Frenzel, P., Derakshani, M. \& Liesack, W. (2005). Succession of bacterial community structure and diversity in a paddy soil oxygen gradient. Environ Microbiol 7, 382-395.

Nüsslein, B., Chin, K. J., Eckert, W. \& Conrad, R. (2001). Evidence for anaerobic syntrophic acetate oxidation during methane production in the profundal sediment of subtropical Lake Kinneret (Israel). Environ Microbiol 3, 460-470.

Pester, M. \& Brune, A. (2006). Expression profiles of fhs (FTHFS) genes support the hypothesis that spirochaetes dominate reductive 
acetogenesis in the hindgut of lower termites. Environ Microbiol 8, 1261-1270.

Petersen, S. P. \& Ahring, B. K. (1991). Acetate oxidation in a thermophilic anaerobic sewage-sludge digestor: the importance of non-aceticlastic methanogenesis from acetate. FEMS Microbiol Ecol 86, 149-158.

Rothfuss, F. \& Conrad, R. (1993). Thermodynamics of methanogenic intermediary metabolism in littoral sediment of Lake Constance. FEMS Microbiol Ecol 12, 265-276.

Ryan, P., Forbes, C., McHugh, S., O'Reilly, C., Fleming, G. T. \& Colleran, E. (2010). Enrichment of acetogenic bacteria in high rate anaerobic reactors under mesophilic and thermophilic conditions. Water Res 44, 4261-4269.

Salmassi, T. M. \& Leadbetter, J. R. (2003). Analysis of genes of tetrahydrofolate-dependent metabolism from cultivated spirochaetes and the gut community of the termite Zootermopsis angusticollis. Microbiology 149, 2529-2537.

Sansone, F. J. \& Martens, C. S. (1981). Methane production from acetate and associated methane fluxes from anoxic coastal sediments. Science 211, 707-709.

Schauder, R., Widdel, F. \& Fuchs, G. (1987). Carbon assimilation pathways in sulfate-reducing bacteria II. Enzymes of a reductive citric acid cycle in the autotrophic Desulfobacter hydrogenophilus. Arch Microbiol 148, 218-225.

Schink, B. (1997). Energetics of syntrophic cooperation in methanogenic degradation. Microbiol Mol Biol Rev 61, 262-280.

Schnürer, A., Schink, B. \& Svensson, B. H. (1996). Clostridium ultunense sp. nov., a mesophilic bacterium oxidizing acetate in syntrophic association with a hydrogenotrophic methanogenic bacterium. Int J Syst Bacteriol 46, 1145-1152.

Schnürer, A., Svensson, B. H. \& Schink, B. (1997). Enzyme activities in and energetics of acetate metabolism by the mesophilic syntrophically acetate-oxidizing anaerobe Clostridium ultunense. FEMS Microbiol Lett 154, 331-336.

Schnürer, A., Zellner, G. \& Svensson, B. H. (1999). Mesophilic syntrophic acetate oxidation during methane formation in biogas reactors. FEMS Microbiol Ecol 29, 249-261.

Shigematsu, T., Tang, Y., Kobayashi, T., Kawaguchi, H., Morimura, S. \& Kida, K. (2004). Effect of dilution rate on metabolic pathway shift between aceticlastic and nonaceticlastic methanogenesis in chemostat cultivation. Appl Environ Microbiol 70, 4048-4052.

Speece, R. E. (1996). Anaerobic Biotechnology for Industrial Wastewaters. Nashville, TN: Archae Press.

Talbot, G., Topp, E., Palin, M. F. \& Massé, D. I. (2008). Evaluation of molecular methods used for establishing the interactions and functions of microorganisms in anaerobic bioreactors. Water Res 42, 513-537.

Tamura, K., Dudley, J., Nei, M. \& Kumar, S. (2007). MEGA4: Molecular Evolutionary Genetics Analysis (MEGA) software version 4.0. Mol Biol Evol 24, 1596-1599.

Thauer, R. K. (1988). Citric-acid cycle, 50 years on. Modifications and an alternative pathway in anaerobic bacteria. Eur J Biochem 176, 497508.

Thompson, J. D., Gibson, T. J., Plewniak, F., Jeanmougin, F. \& Higgins, D. G. (1997). The CLUSTAL_X windows interface: flexible strategies for multiple sequence alignment aided by quality analysis tools. Nucleic Acids Res 25, 4876-4882.

Ueno, Y., Haruta, S., Ishii, M. \& Igarashi, Y. (2001). Changes in product formation and bacterial community by dilution rate on carbohydrate fermentation by methanogenic microflora in con tinuous flow stirred tank reactor. Appl Microbiol Biotechnol 57, 65-73.

Westerholm, M., Roos, S. \& Schnürer, A. (2010). Syntrophaceticus schinkii gen. nov., sp. nov., an anaerobic, syntrophic acetate-oxidizing bacterium isolated from a mesophilic anaerobic filter. FEMS Microbiol Lett 309, 100-104.

Zehnder, A. J. B. \& Stumm, W. (1988). Geochemistry and biochemistry of anaerobic habitats. In Biology of Anaerobic Microorganisms, pp. 1-38. Edited by A. J. B. Zehnder. New York: Wiley Interscience.

Zinder, S. H. (1994). Syntrophic acetate oxidation and "reversible acetogenesis". In Acetogenesis, pp. 387-415. Edited by H. L. Drake. New York: Chapman \& Hall.

Zinder, S. H. \& Koch, M. (1984). Non-aceticlastic methanogenesis from acetate: acetate oxidation by a thermophilic syntrophic coculture. Arch Microbiol 138, 263-272.

Edited by: H. Daims 